\title{
Effect of Gestational Biological, Social, Economic Factors on Undernutrition in Infants 6-12 Months in Cilacap
}

\author{
Majestika Septikasari1), Muhammad Akhyar²), Budiyanti Wiboworini3) \\ ${ }^{1)}$ School of Health Al-Irsyad Al-Islamiyyah Cilacap, Central Java \\ ${ }^{2)}$ Faculty of Teaching and Educational Sciences, Sebelas Maret University, Surakarta \\ ${ }^{3)}$ Faculty of Medicine, Sebelas Maret University, Surakarta
}

\begin{abstract}
Background: Undernutrition in children under five can cause disorder in the physical growth, mental development, low intellegence, or even death. This study aimed to test the hypothesis that under nutrition in infants aged 6-12 months is associated with gestational biological, social, and economic factors.

Subjects and Method: This was an analytic and observational study with case control design. This study was conducted in Cilacap, Central Java. A total of 144 infants aged 6-12 months were selected by fixed disease sampling, consisting of 72 undernutrition cases and 72 control. The dependent variable was undernutrition. The independent variables were birthweight, breastfeeding complementary food intake, exclusive breastfeeding, maternal education, paternal education, family income, MUAC at pregnancy, intra-household food allocation, and rural-urban residence. The data were collected by questionnaire and anthropometry. The data were analyzed by multiple logistic regression.

Results: Birthweight <2500 gram ( $\mathrm{OR}=8.12 ; 95 \% \mathrm{CI}=0.92$ to $71.64 ; \mathrm{p}=0.059)$, inadequate intake of breastfeeding complementary food ( $\mathrm{OR}=3.93 ; 95 \% \mathrm{CI}=1.59$ to $9.75 ; \mathrm{p}=0.003)$, and nonexclusive breastfeeding ( $\mathrm{OR}=2.46 ; 95 \% \mathrm{CI}=1.13$ to $5.36 ; \mathrm{p}=0.023)$ increased the risk of undernutrition in infants aged 6-12 months. Paternal education $(\mathrm{OR}=1.50 ; 95 \% \mathrm{CI}=0.61$ to 3.71 ; $\mathrm{p}=0.377)$, family income $(\mathrm{OR}=2.54 ; 95 \% \mathrm{CI}=1.03$ to $6.28 ; \mathrm{p}=0.43)$, MUAC $(\mathrm{OR}=1.32 ; 95 \%$ $\mathrm{CI}=0.512$ to $3.38 ; \mathrm{p}=0.562)$, intra-household food allocation $(\mathrm{OR}=1.84 ; 95 \% \mathrm{CI}=0.85$ to 4.02 ; $\mathrm{p}=0.123)$, maternal education $(\mathrm{OR}=0.78 ; 95 \% \mathrm{CI}=0.31$ to $1.97 ; \mathrm{p}=0.599)$ and rural-urban residence $(\mathrm{OR}=0.82 ; 95 \% \mathrm{CI}=0.36$ to $1.85 ; \mathrm{p}=0.630)$ had non-significant effect on the risk of undernutrition in infants aged 6-12 months.

Conclusion: Birthweight $<2,500 \mathrm{~g}$, inadequate intake of breastfeeding complementary food, and non-exclusive breastfeeding increase the risk of undernutrition in infants aged 6-12 months. Paternal education, family income, MUAC, intra-household food allocation, maternal education and rural-urban residence have non-significant effect on the risk of undernutrition in infants aged 6-12 months.
\end{abstract}

Keywords: birthweight, gestational, biological, social, economic factors, undernutrition, infants aged 6-12 months

\section{Correspondence:}

Majestika Septikasari. School of Health Al-Irsyad Al-Islamiyyah Cilacap, Central Java.

Email: jeaflava@gmail.com

\section{BACKGROUND}

Undernutrition in children under five can cause physical-growth disorder, mental development and degrading intelligence, even death (Bappenas, 2013). Undernutrition in children under five happens because of the inadequacy of nutrient intake, and the presence of diseases. Both causes are influenced by maternal, social-economic, demographic and behavioral factors. (Chikhungu et al., 2014). Nutritional status in children under five is also influenced by growth levels and their previous development which are started from the period of 
conception as far as the age of two or is known as the first thousand days of life (Cunha et al., 2015).

Undernutrition in pregnancy will affect a fetus' nutritional status accumulatively which will be reflected in prematurity (Karima dan Achadi, 2012). Children under five who are born prematurely have 3.34 more risks to experience undernourishment than those who are not (Arnisam, 2007). Nutritional status has direct influence to nutrient intake. The nutritional needs of a newborn baby up to six months old are fulfilled by breastmilk without any additional solids or liquids which is referred as exclusive breastfeeding. The length of time on exclusive breastfeeding has positive effects on the physical growth in children under five based on body weight/age (BW/A) and body weight/height (BW/H) as it is stated in WHO-NCHS reference (Lepita et al., 2009). Over six month old, breast milk fulfills $60 \%$ of nutritional needs. Therefore, over six month old, an infant needs to be fed with complementary foods up to two years old.

Parents' educational stages are also associated to nutritional status of children under five (Sebataraja et al., 2014). Children under five with adequate nutrition are often found with parents who are highly educated (Bharati et al., 2010). Nutritional status on children under five is also influenced by household income. Based on the research conducted in Jayapura, it indicated that there was a consequential correlation between household income and nutritional status on children under five (Persulessy, 2012). Family with higher standard of life tends to have healthier children under five than family with lower standard of life (Bharati et al., 2010). Another research revealed that household expense was one of the important determinants of nutritional status on children under five (Masiye et al., 2010).

Besides socioeconomic factor, nutritional status in children under five is also influenced by residential topographic area. Referring to a study conducted at coastal and ridgeline area in district of Jepara, there was a significant difference between the level of protein consumption in children under five who lived in the coastal area to those lived at the ridgeline (Auliya et al., 2015). Another study revealed that the average nutritional status on urban children was higher than that of suburban children (Falasifah dan Noor, 2014).

This research aimed to understand the effects of biological (Mid-Upper Arm Circumference at the early stage of pregnancy, birthweight, successful exclusive breastfeeding and complementary food intake), socioeconomic (maternal and paternal education, household expenses and intra-household food allocation) and geographic (rural-urban residence) factors in the first thousand days of life to undernutrition in children aged 6-11 months in district of Cilacap.

\section{SUBJECTS AND METHOD}

This research implemented the observational analitical study design using a case control approach. This research was conducted in district of Cilacap from January to July 2016. Population at the time of the research was infants aged 6-11 months in district of Cilacap, which were 14,728 . Samples were taken using fixeddisease sampling technique as many as 144 samples consisted of 72 cases and 72 controls.

The data on the infants' nutritional status were obtained through weighing which then being transformed to a Z-score. The data on MUAC at early pregnancy and birthweight were obtained through nursing 
documentation study (book of Mother and Child's Health Record). Data on the success of exclusive breastfeeding, complementary food intake, maternal education, paternal education, household expenses, intrahousehold food allocation and urbansuburban residential area were taken from questionnaire. Data analysis was logistic regression.

\section{RESULT}

Based on the research, it is known that as much as $23.65 \%$ of the research subjects have a history of gestational chronic energy deficiency (GCED). On the variable of birthweight, research subjects with history of low birthweight (LBW) are as much as 6.9\%. Research subjects with history of

Table 1. Logistic regression analysis results on the effect of biological, socioeconomic and geographic factors in the first thousand days of life to undernutrition in infants aged 6-11 months in district of Cilacap

\begin{tabular}{|c|c|c|c|c|}
\hline \multirow{2}{*}{ Variable } & \multirow{2}{*}{$\mathbf{O R}$} & \multicolumn{2}{|c|}{ CI 95\% } & \multirow{2}{*}{$\mathbf{p}$} \\
\hline & & Lower Limit & Upper Limit & \\
\hline MUAC early pregnancy $(<23.5 \mathrm{~cm})$ & 1.32 & 0.51 & 3.38 & 0.562 \\
\hline Birthweight $(<2500 \mathrm{~g})$ & 8.12 & 0.92 & 71.64 & 0.059 \\
\hline Unsuccessful exclusive breasfeeding & 2.46 & 1.13 & $5 \cdot 36$ & 0.023 \\
\hline Inadequate complementary food intake & 3.93 & 1.59 & 9.75 & 0.003 \\
\hline Maternal Education ( $<$ Senior High School) & 0.78 & 0.31 & 1.97 & 0.599 \\
\hline Paternal Education (<Senior High Shool) & 1.50 & 0.61 & 3.71 & 0.377 \\
\hline Household Expenses (Rp. 2,255,00o) & 2.54 & 1.03 & 6.28 & 0.043 \\
\hline Intra-household Food Alocation (low) & 1.85 & 0.85 & 4.02 & 0.123 \\
\hline Residential Area (rural) & 0.82 & 0.36 & 1.85 & 0.630 \\
\hline N Observation & 144 & & & \\
\hline -2 log likedkehood & 166.94 & & & \\
\hline Nagelkerke $\mathrm{R}^{2}$ & $27.1 \%$ & & & \\
\hline
\end{tabular}

Based on the result of logistic regression's equation, it appears that there is a weak effect on MUAC at the early stage of pregnancy $(\mathrm{OR}=1.32$; CI 95\%=0.512-3.38; $\mathrm{p}=0.562)$ to the risks of undernutrition in infants aged 6-11 months.

Infants whose mothers have MUAC $<23.5 \mathrm{~cm}$ have 1.3 times more risks to experience undernutrition than those whose mothers do not have MUAC < 23.5 unsuccessful exclusive breastfeeding are as much as $56.35 \%$. Inadequate complementary food is $71.5 \%$. Most of the maternal and paternal education are Senior High School graduates. Those numbers are 42.2\% for maternal education and 44.4\% for paternal education. Most of the household expenses made by these research subjects are categorized as high, which reach the percentage of $75 \%$. Intra-household food allocation made by research subjects falls into low category as shown by a percentage of $57.6 \%$. As much as $41 \%$ research subjects live in the farming area, $39.6 \%$ live in the urban area and $19.4 \%$ live around the coastline. cm. However, that effect is statistically insignificant. It is the birthweight $(\mathrm{OR}=$ 8.12; CI $95 \%=0.92$ to $71.76 ; p=0.059$ ) that will strongly affect the risks of undernutrition in infants aged 6-11 months.

Infants with histories of low birthweight (LBW) will increase undernutrition risks up to 8 times more than those without. The effect of birthweight to under- 
nutrition in infants aged 6-11 months is statistically significant.

The variable on successful exclusive breastfeeding $(\mathrm{OR}=2.46$; $\mathrm{CI} 95 \%=1.13$ to 5.36; $\mathrm{p}=0.023$ ) has medium effect to undernutrition in infants aged 6-11 months. Infants with histories of unsuccessful exclusive breastfeeding will increase the risk of undernutrition to as much as 2.5 times more than those without. The effect of whether or not infants aged 6-11 months have successful exclusive breastfeeding to the risk of undernutrition is statistically significant. There is a strong effect on complementary food intake $(\mathrm{OR}=3.93$; $\mathrm{CI}$ $95 \%=1.59$ to $9.75 ; \mathrm{p}=0.003$ ) to the risk of undernutrition in infants aged 6-11 months. Infants that have inadequate intake of complementary foods will increase the risk of undernutrition to four times more than those who have adequate intake of complementary foods. The effect of complementary foods to undernutrition in infants aged 6-11 months is statistically significant.

The variable on maternal education (OR=0.78; CI $95 \%=0.31$ to $1.97 ; \mathrm{p}=0.599)$ has inverse (negative) effect to the risk of undernutrition in infants aged 6-11 months, and that effect is statistically insignificant. However, the variable on paternal education $(\mathrm{OR}=1.5 \mathrm{O}$; CI $95 \%=0.61-3.71 ; \mathrm{p}=$ 0.377) shows a medium effect to the risk of undernutrition in infants aged 6-11 months. Infants whose fathers are low-educated will increase the risk of undernutrition in infants aged 6-11 months to 1.5 more than those whose fathers are highly-educated. The effect of paternal education to undernourished infants aged 6-11 months is statistically insignificant. There is a medium effect on the variable of household expenses $(\mathrm{OR}=2.54$; $\mathrm{CI} 95 \%=1.03-6.28$; $\mathrm{p}=$ 0.043) to the risk of undernutrition in children. Low household expenses will increase the risk of undernutrition to as much as 2.6 times more than high household expenses. The effect of household expenses to the risk of undernutrition in infants aged 6-11 months is statistically significant.

The result of this research also indicates that there is a weak effect on the variable of intra-household food allocation to the risk of undernutrition in infants aged 6-11 months. The effect of intra-household food allocation (OR=1.85; CI $95 \%=0.85$ to 4.02; $p=0.123$ ) to undernutrition in infants aged 6-11 months is statistically insignificant. Low intra-household food allocation will increase the risk of undernutrition to 1.9 times more than high intra-household food allocation.

The variable of residential area ( $\mathrm{OR}=0.82 ; \mathrm{CI} 95 \%=0.36$ to $1.85 ; \mathrm{p}=0.630$ ) has inverse (negative) effect to the risk of undernutrition in infants aged 6-11 months and that effect is statistically insignificant. The value of Negelkerke R2 is $\mathbf{2 7 . 1 \%}$ which means that the free variables (MUAC during early pregnancy, birthweight, successful exclusive breastfeeding, complementary food intake, maternal and paternal education, household expenses, intrahousehold food allocation and residence) are capable of explaining the effects on the risk to undernutrition in infants aged 6-11 months as much as $\mathbf{2 7 . 1 \%}$ whereas the rest of it, which is $79.3 \%$, is explained by other factors beyond this research model.

\section{DISCUSSION}

Pre-pregnancy nutritional status can be measured from body mass index (BMI) and mid-upper arm circumference (MUAC). Based on the research findings by Babatunde et al., (2011), a mother's BMI was one of the influencial factors to children's nutritional status. In Indonesia, prepregnancy body weight is generally unknown. Thus, the use of MUAC becomes 
a general practice to decide pre-pregnancy nutritional status. A mother's MUAC which is less than $23.5 \mathrm{~cm}$ is one of the indicators to pronounce chronic lack of energy status (CLE). CLE will prevent the fetus to develop optimally (Ariyani et al., 2012). A mother experienced CLE will cause disturbance to the functions of umbilical cord that is shown by its relatively small weight and size. A mother's CLE will reduce blood volume expansion that causes insufficient cardiac output. Therefore, the blood flow to umbilical cord will decrease so as its size will not be optimal and will also decrease nutritional distribution to fetus that can cause an obstruction to the fetus' development (Karima dan Achadi, 2012). This is in accordance with the research conducted in Sawahlunto-Sijujung in 2007 which stated thats a mother experienced CLE had risk to giving birth to an infant with low birthweight 4.8 times more than a mother who had not (Ariyani et al., 2012).

However, in this research, the effect of early pregnancy MUAC to undernutrition in infants aged 6-11 months was statistically insignificant. This might be caused by the MUAC that was taken in the early pregnancy. The heavy body weight gain during pregnancy will affect the birthweight. This result suits the research finding presented by Karima dan Achadi, 2012 which concluded that a mother's weight gain during pregnancy would influence birthweight.

Infants who are born with low birthweights (LBW) have chances to experience disturbance in their nerve systems so as their growths and developments will be slower than those with normal birthweight (Correia et al., 2014). Infants with LBW are more susceptible to infections if not being supported by adequate nutrient intake. Thus, they will be at more risks to be undernourished or malnourished in the future (Rosha et al., 2013).

The research previously conducted in Brazil had concluded that the history of LBW had significantly correlated with undernourishment, stunting and wasting in children under five (Correia et al., 2014). Such result of research is similar to the one conducted in Ulee Kareng, Banda Aceh which indicated that children under five with LBW had 3.34 times more risks to experience undernutrition than those who did not have LBW (Arnisam, 2007).

Although the effect of an infants' LBW to undernutrition in infants aged 6-11 months was evident, this was not statistically significant. This might happen because of the small sample amount. Out of 144 research subjects, only 10 of them experienced LBW, among 9 of which experienced undernutrition and only one was well-nourished.

The effect of successful exclusive breastfeeding to undernutrition in infants aged 6-11 months was statistically significant. Breastmilk is the most ideal food for a newborn baby until 6 months old because it contains essensial nutrition for a newborn's growth and development. Breastmilk is not only contained highly nutritious substances for infants' growing processes, nerve systems and brain developments, but also immunity substance to help infants not to get sick easily. Colostrum in breastmilk is the best antibody that is able to protect infants from infections and diseases (Roesli, 2012). Exclusive breastfeeding is associated with nutritional status in children under five. This appeared in the result of a research conducted in Bangladesh which found that undernutrition was more frequently occurred to children under five who were breastfed for less than 24 months (Rabbi and Karmaker, 2014). Based on the research in West 
Padang, the result indicated that $80 \%$ among infants who had been exclusively breastfed had normal nutritional status (Nilakesuma et al., 2015). The duration in exclusive breasfeeding has positive effect on the growth of children under five. It was measured based on the percentage on median $\mathrm{BW} / \mathrm{A}$ and $\mathrm{BW} / \mathrm{H}$ stated as a basic reference from WHO-NCHS (Lepita et al., 2009).

Above six months old, breastmilk fulfills only $60 \%$ of the nutritional needs. Thus, complementary foods need to be given until children reach two years of age. Complementary foods must contain all necessary nutrition needed, such as carbohydrates, protein, fat, vitamins, minerals and water with regards of cleanliness and safety for infants (Cunha et al., 2015).

In feeding complementary foods, parents must concern on few things. One of them is the right time. Feeding complementary foods too early can cause indigestion in infants because infants' digestion systems are not physiologically ready for solid foods. Thus, will result in diarrhea or constipation. In addition to it, feeding complementary foods too early may increase the risks of obesity, allergic reactions and declining immunity that is caused by decreasing breastmilk consumption. Complementary foods should not be given too late either. Being late in feeding complementary foods will affect on the unfulfillment of infants' nutrition needs (Krisnatuti, 2008).

Based on few studies that had been done previously, correlation between feeding complementary foods and nutrition status in children under five was perceptible. The research conducted in the working area of public health centre at Gedong Tengen, Yogyakarta indicated a significant correlation between the pattern in feeding complementary foods and nutritional status on infants aged 6-24 months (Septiana et al., 2010). This result is the same as the previous research conducted in district of Setabelan, Surakarta. The result of that research indicated that there was a significant correlation between feeding complementary foods and nutritional status in infant aged 6-24 months (Wardhani, 2015).

The result of this research indicated that there was an inversed effect on maternal education to the risk of undernutrition in infants aged 6-11 months. However, that effect was statistically insignificant. This result is in accordance with the previous research conducted by Mathew Mindo, which stated that there was no significant correlation between maternal education level and an infant's nutritional status (Simangunsong, 2009).

A primary school graduate will have different level of knowledge about nutrition to compare to those who have higher education. However, this does not mean that a primary school graduate is less able to arrange nutritious food. A diligent mother who likes reading any information about nutrition or takes part in some nutrition counseling is possible to have better knowledge on nutrition eventhough she has low level of education. However, a mother who has a higher level of education certainly will be able to perceive any messages and information easily (Nilakesuma et al., 2015). Education at one point has positive effect. That is when a mother gets better understanding on the importance of health maintenance. However, at another point, a higher education has effect on the changes of social values that influence the healthy life style including food consumption.

Level of education is very influencial to anyone in understanding and receiving any information he or she obtained (Sebataraja et al., 2014). The higher the 
level of education is, the easier it is to understand any information given, and the easier it is to implement her knowledge in her behavior especially in relation to health and nutrition (Putri et al., 2015). Loweducation level will correlate with the parents' attitude and behavior in solving undernutrition in their children under five (Putri et al., 2015). Parents who are well educated will understand how to nurse their children well, how to use health facilities well and how to take care of the environment's cleanliness (Rosha et al., 2013). The previous findings on research conducted in West Sumatra indicated that low-educated parents (Primary School or lower graduates) had bigger risks to the quality of their children's nutrition whereby the probability of the risk of being malnourished was 5.6 times more than highereducated parents (Saputra dan Nurrizka, 2012). The values existed in society that place men as the sources of household income cause the lack of paternal roles in organizing household including child care and nutrition for family. This might be the cause of the research result as being statistically insignificant.

Household expenses are commonly used to measure household socioeconomic state because to obtain such accurate data is difficult (Hastuti et al., 2011). A household economic state can guarantee the fulfillment of basic needs for each of the family members, and one of them is the needs of nutrition. The amount and quality of food for the family are determined by the level of household income (Sebataraja et al., 2014). A family with higher life standard tends to have well-nourished children under five to compare to a family with lower life standard (Bharati et al., 2010). A previous research conducted in Pakistan indicated that the society from mid-tolower economic status had risks of undernourishment as the impact on the lackness of nutritious food. A similar research was conducted in Pati which also indicated that the smaller the family income was, the more percentage shown on undernourished children (Falasifah dan Noor, 2014). According to Hanani (2009), poverty has made the access to jobs and resource management becomes low, thus, will cause a low society income. Low income causes the society's purchasing power becomes low too. Low purchasing power causes the basic needs, those are the needs for food that meets the food patterns as the requirement to be considered as well nourished, to have more opportunities to be unfulfiled.

Intra-household food allocation has effect on the percentage of expenses used for food. It means that if the percentage for food expenses is high, it will guarantee the availability of family nutrient intake especially for children under five as the delicate group. In this research, the influence of intra-household food allocation was statistically insignificant. The cause might be the fact that despite there were more expenses on food than non-food, it did not mean that the food consumed contained adequate nutrition. Daily food consumption should be varied and include the kinds of staple food, nuts, meat and food produced from animals, all kinds of vegetables, fruits and fat (Depkes RI, 2011). In addition to it, food has to be properly processed so as not to ruin the nutrition in it.

The result of this research indicated that there was an inverse (negative) effect between residential area and the risk of undernutrition in infants aged 6-11 months. This effect was statistically insignificant. This result is in accordance to the previous research which was conducted in Jepara, West Java in 2009. Its result stated that the 
Indonesian Journal of Medicine (2016), 1(3): 184-194 https://doi.org/10.26911/theijmed.2017.02.01.06

residential topography did not make any influences to nutritional status on children under five (Auliya et al., 2015).

The result of this research is supported by the previous research conducted by Falasifah and Noor (2014). Their findings indicated that there were not any differences on energy intakes in urban group, nor sub-urban group. The result of this research indicated a negative correlation between residential area and undernutrition in infants aged 6-11 months. This can be caused by the unhealthy people that tend to eat fast food. Besides, nursing habit in urban area that has the tendency of hiring a nanny may make it possible for the cause of undernutrition in children living in the urban area. Urban area which is also an area for industrial centre may cause environmental sanitation to become lesser than what considered to be good so as increasing the risk of infectious diseases which is directly associated with an infant's nutritional status. This is in accordance with the statement UNICEF made that environmental sanitation influences an infant's nutritional status.

Based on this research findings, it can be concluded that birthweight $(\mathrm{OR}=8.12$; $95 \% \mathrm{CI}=0.92$ to $71.64 ; \mathrm{p}=0.059)$ and complementary food intake (OR=3.93; 955 $\mathrm{CI}=1.59$ to $9.75 ; \mathrm{p}=0.003$ ) have strong correlation to undernutrition in infants aged 6-11 months. Exclusive breastfeeding $(\mathrm{OR}=2.46 ; 95 \% \mathrm{CI}=1.13$ to $5.36 ; \mathrm{p}=0.023)$, paternal education $(\mathrm{OR}=1.50 ; 95 \% \mathrm{CI}=0.61$ to $3.71 ; \mathrm{p}=0.377)$ and household expenses $(\mathrm{OR}=2.54 ; 95 \% \mathrm{CI}=1.03$ to $6.28 ; \mathrm{p}=0.43)$ have medium effect. A mother's MUAC in her early pregnancy $(\mathrm{OR}=1.32$; $95 \% \mathrm{CI}=$ 0.51 to $3.38 ; \mathrm{p}=0.562$ ) and intra-household food allocation $(\mathrm{OR}=1.84 ; 95 \% \mathrm{CI}=0.85$ to 4.02; $\mathrm{p}=0.123$ ) have low effect. Whereas maternal education $(\mathrm{OR}=0.78 ; 95 \% \mathrm{CI}=$ 0.31 to $1.97 ; \mathrm{p}=0.599$ ) and residential area
$(\mathrm{OR}=0.82 ; 95 \% \mathrm{CI}=0.36$ to $1.85 ; \mathrm{p}=0.630)$ have negative effect.

\section{REFERENCE}

Achadi EL (2014). Periode Kritis 1000 Hari Pertama Kehidupan dan Dampak Jangka Panjang terhadap Kesehatan dan Fungsinya. Kursus Penyegar Ilmu Gizi PERSAGI. Yogyakarta, 25 November 2014.

Ariyani DE, Achadi EL, Irawati A (2012). Validitas Lingkar Lengan Atas Mendeteksi Risiko Kekurangan Energi Kronis pada Wanita Indonesia. Jurnal Kesehatan Masyarakat Nasional 7(2): 83-89.

Arnisam (2016). Hubungan Berat Badan Lahir Rendah (BBLR) dengan Status Gizi Anak Usia 6-24 Bulan. http://etd.repository.ugm.ac.id.

Auliya C, Woro KH, Budiono I (2015). Profil Status Gizi Balita Ditinjau dari Topografi Wilayah Tempat Tinggal (Studi di Wilayah Pantai dan Wilayah Punggung Bukit Kabupaten Jepara). Unnes Journal of Public Health 4 (2): 108-116.

Babatunde RO, Olagunju FI, Fakayode SD, Sola-Ojo FE (2011). Prevalence and Determinants of Malnutrition among Under Five Children of Farming Households in Kwara State, Nigeria. Journal of Agricultural Science, 3(3): 173-181.

Bappenas (2013). Periode Emas pada 1000 Hari Pertama Kehidupan. Buletin 1000 Hari Pertama Kehidupan, 1(1): 1-4.

Bharati S, Chakrabarty S, Som S, Pal M, Bharati P (2010). Socio-Economic Determinants of Underweight Children in West Bengal, India. Asian Pacific Journal of Tropical Medicine 3 (4): 322-327. 
Chikhungu, Madise, Padmadas (2014). How Important are Community Characteristics in Influencing Children's Nutrition Status? Evidence from Malawi Population-Based Household and Community Surveys. Health \& Place Journal 30(1): 187-195

Correia LL, Silvia AC, Campos JS, Andrade FM, Machando MMT, Lindsay AC, Leite AJM (2014). Prevalence and Determinants of Child Undernutrition and Stunting in Semiarid Region of Brazil. Revista de Saúde Pública 48(1): 19-28

Cunha AJLA, Leite AJM, Almeida IS (2015). The Pediatrician's Role in The First Thousand Days of The Child: The Pursuit of Healthy Nutrition and Development. Jornal de Pediatrica, 91 (6): 44-51

Depkes RI (2011). Pelatihan Konseling Makanan Pendamping Air Susu Ibu. Direktorat Gizi Masyarakat.

Depkes RI (2015). Situasi Kesehatan Anak Balita di Indonesia. InfoDatin 8 April

Murti B (2011). Kesehatan Anak dan Epidemiologi Sepanjang Hayat. Jurnal Kedokteran Indonesia, 2(1): 1-4.

Dinas Kesehatan Kab. Cilacap (2014). Profil Kesehatan Kabupaten Cilacap 2014. Dinas Kesehatan Kabupaten Cilacap

Falasifah U, Noor ER (2014). Perbedaan Asupan Energi, Aktivitas Fisik dan Status Gizi antara Anak Usia 4-5 Tahun di Taman Kanak-Kanak Daerah Urban dan Suburban. Journal of Nutrition Collage. 3 (4): 988-993.

Ferial EW (2011). Hubungan antara Status Gizi Ibu Berdasarkan Ukuran Lingkar Lengan Atas (LILA) dengan Berat Badan Lahir Bayi di RSUD Daya Kota Makasar. Jurnal Alam dan Lingkungan 2(3): 11-21.

Hanani N (2009). Monitoring dan Evaluasi Ketahanan Pangan. http://lecture. brawijaya.ac.id/nuhfil/files/2009/o3 /7pemetaan-rawan-pangan-7.pdf. Diakses 30 Mei 2016.

Hastuti D, Fiernanti DYI, Guhardja S (2011). Kualitas Lingkungan Pengasuhan dan Perkembangan Sosial Emosi Anak Usia Balita di Daerah Rawan Pangan. Jurnal Ilmu Keluarga dan Konsumen 4(1): 57-56.

Jesmin A, Yamamoto SS, Malik AA, Haque MA (2011). Prevalence and Determinants of Chronic Malnutrition among Preschool Children: A Crosssectional Study in Dhaka City, Bangladesh. Journal of Health, Population and Nutrition, 29 (5): 494-499.

Karima K, Achadi EL (2012). Status Gizi Ibu dan Berat Badan Lahir Bayi. Jurnal Kesehatan Masyarakat Nasional 7(3): 111-119.

Kementerian Kesehatan Republik Indonesia (2010). Peraturan Menteri Kesehatan Republik Indonesia tentang Penggunaan Kartu Menuju Sehat (KMS) bagi Balita. Direktorat Jenderal Bina Kesehatan Masyarakat.

Kementerian Kesehatan Republik Indonesia (2011). Keputusan Menteri Kesehatan Republik Indonesia Nomor:1195/ MENKES/ SK/ XII/ 2010 tentang Standar Antropometri Penilaian Status Gizi Anak. Direktorat Jenderal Bina Gizi dan Kesehatan Ibu dan Anak.

Krisnatuti D (2008). Menyiapkan Makanan Pendamping ASI. Jakarta: Puspa Swara.

Lepita, Sukandar H, Wirakusumah FF (2009). Evaluasi Pengaruh Lamanya Pemberian ASI Saja terhadap Pertumbuhan Anak. Bandung Medical Journal 41 (1): 27-31.

Masibo PK (2013). Trends and Determinants of Malnutrition among Children Age 0-59 months in Kenya (KD HS 
1993, 1998, 2003 and 2008-9). DHS Working Papers No 89.

Masiye F, Chama C, Chitah B, Jonsson D (2010). Determinants of Child Nutritional Status in Zambia: An Analysis of a National Survey. Zambia Social Science Journal, 1(1): 29-42.

Nilakesuma A, Jurnalis YD, Rusjdi SR (2015). Hubungan Status Gizi Bayi dengan Pemberian ASI Eksklusif, Tingkat Pendidikan Ibu dan Status Ekonomi Keluarga di Wilayah Kerja Puskesmas Padang Pasir. Jurnal Kesehatan Andalas, 4(1): 37-44.

Persulessy V (2012). Hubungan Tingkat Pendapatan dan Pola Makan dengan Status Gizi Balita di Daerah Nelayan Distrik Jayapura Utara Kota Jayapura.http://etd.repository.ugm.ac.id.

Diakses 27 Januari 2016.

Putri RF, Sulastri D, Lestari Y (2015). Faktor-Faktor yang Berhubungan dengan Status Gizi Anak Balita di Wilayah Kerja Puskesmas Nanggalo Padang. Jurnal Kesehatan Andalas. 4 (1): 254-261.

Pongou R, Ezzati M, Salomon JA (2006). Household and Community Socioeconomic and Environmental Determinant of Child Nutritional Status in Cameroon. BMC Public Health Journal. 6 (98): 1-19.

Rabbi AMF, Karmaker SC (2014). Determinants of Child Malnutrition in Bangladesh-A Multivariate Approach. Asian Journal of Medical Sciences 6 (2): 85-90.

Riyadi H, Khomsan A, Dadang S, Faisal A, Mdjajanto ES (2006). Studi Tentang Status Gizi pada Rumah Tangga Miskin dan Tidak Miskin. Jurnal Gizi Indonesia 29 (1): 1-8.

Roesli U. (2012) Panduan Inisiasi Menyusu Dini Plus ASI Eksklusif. Jakarta: Pustaka Bunda.
Rosha BC, Putri DSK, Putri IYS (2013). Determinan Status Gizi Pendek Anak Balita dengan Riwayat Berat Badan Lahir Rendah (BBLR) di Indonesia (Analisis Data Riskesdas 2007-2010). Jurnal Ekologi Kesehatan, 12(3): 195205.

Santoso B, Sulistiowati E, Sekartuti, Lamid A (2013). Kementrian Kesehatan RI, Pokok-Pokok Hasil Riskesdas Provinsi Jawa Tengah 2013. Jakarta: Lembaga Penerbitan Badan Litbangkes.

Saputra W, Nurrizka RH (2012). Faktor Demografi dan Risiko Gizi Buruk dan Gizi Kurang. Makara Journal of Health Research, 16(2): 95-101.

Sebataraja LR, Oenzeil F, Asterina (2014) Hubungan Status Gizi dengan Status Sosial Ekonomi Keluarga Murid Sekolah dasar di Daerah Pusat dan Pinggiran Kota Padang. Jurnal Kesehatan Andalas, 3(2): 182-187.

Semba RD, Kalm LM, Pee S, Ricks MO, Sari M, Bloem MW (2007). Paternal Smoking is Associated with Increased Risk of Child Malnutrition among Poor Urban Families in Indonesia. Public Health Nutrition Journal, 10(1): 7-15.

Septiana R, Djanah RSN, Djamil MD (2010) Hubungan antara Pola Pemberian Makanan Pendamping ASI (MP-ASI) dan Status Gizi Balita usia 6-24 Bulan di Wilayah Kerja Puskesmas Godongtengen Yogyakarta. Jurnal Kesehatan Masyarakat, 4(2): 118-124.

Simangunsong MM. (2009) Hubungan antara Status Gizi Bayi dengan Jenis Kelamin Bayi, Diare, dan ISPA 14 Hari Terakhir, Pemberian ASI Eksklusif, Usia Ibu Saat Melahirkan, Ibu yang Bekerja, tingkat Pendidikan Ibu dan Tingkat penghasilan Keluarga. 
http://lib.ui.ac.id. Diakses 30 Mei 2016.

Soblia ET (2009). Tingkat Ketahanan Pangan Rumah tangga, Kondisi Lingkungan, Morbiditas, Dan Hubungannya Dengan Status Gizi Anak Balita Pada Rumah tangga Di Daerah Rawan Pangan Banjarnegara, Jawa Tengah. http://repository. ipb.ac.id/. Diakses 30 Mei 2016.
WHO (2010). Analisis Lanskap Kajian Negara Indonesia. http://www.who. int. Diakses 27 Januari 2016.

Wardhani GK (2015). Hubungan pemberian makanan pendamping asi dengan status gizi bayi usia 6-24 bulan di kelurahan setabelan Kota Surakarta. https://digilib.uns.ac.id/. Diakses 30 Mei 2016. 